\title{
Penggunaan Google Classroom Sebagai Pengembangan Kelas Virtual dalam Keterampilan Pemecahan Masalah Sebelum dan Saat Pandemi Covid-19
}

\author{
Nia Maharani \\ STMIK STIKOM INDONESIA BALI \\ Email: maharani.nst@gmail.com
}

DOI: https://doi.org/10.33369/pendipa.5.1.23-29

\begin{abstract}
[The use of google classroom as a virtual classroom development in problem solving skills before and during Covid-19 pandemic] This article discusses previous research entitled "The use of google classroom as a virtual classroom development in problem solving skills on kinematics topics for students majoring in computer systems". The use of Google Classroom at that time was an alternative tool to support the face-toface learning process. The problem in the field is that the topic of parabolic motion kinematics is a topic that is considered difficult by students so that aids are needed, one of which is Google Classroom to support the learning process in the classroom. The results of previous research indicate that the use of Google Classroom is effective in supporting the learning process in the classroom (Maharani and Kartini, 2019). Covid-19 hit in Indonesia and even in many countries in the world, learning has been completely carried out online. One of the applications used in the online learning process is Google Classroom. This study aims to see to what extent the effectiveness of Google Classroom in full online learning on the topic of parabolic motion kinematics for students majoring in Computer Systems during the pandemic and before the pandemic. The method is that students are given three test questions related to parabolic motion, then students answer and upload the results to Google Classroom. The test results show that the use of Google Classroom during the pandemic was running optimally. This can be seen from the results of student work and the results of open questionnaires filled out by students. In addition, learning with Google Classroom is effective in supporting the problem-solving skills of these students with the support of other online learning media, namely learning videos containing parabolic motion material along with examples of questions and discussion.
\end{abstract}

Keywords: Information Technology; Google Classroom; Parabolic Motion; Problem Solving Skill; Covid19.

\begin{abstract}
ABSTRAK
Artikel ini membahas tentang penelitian sebelumnya yang berjudul "Penggunaan Google Classroom Sebagai Pengembangan Kelas Virtual Dalam Keterampilan Pemecahan Masalah Topik Kinematika Pada Mahasiswa Jurusan Sistem Komputer. Penggunaan GC saat itu adalah sebagai salah satu alternatif alat bantu untuk mendukumg proses pembelajaran tatap muka. Permasalahan di lapangan adalah topik kinematika gerak parabola merupakan topik yang dianggap sulit oleh mahasiswa sehingga diperlukan media bantu salah satunya adalah GC umtuk mendukung proses pembelajaran di kelas. Dari hasil penelitian sebelumnya menunjukkan bahwa penggunaan GC efektif dalam mendukung proses pembelajaran di kelas (Maharani dan Kartini, 2019). Sejak Covid-19 melanda di Indonesia bahkan banyak negara di dunia, pembelajaran sepenuhnya dilakukan secara online atau daring. Salah satu aplikasi yang digunakan dalam proses pembelajaran online adalah Google Classroom. Penelitian ini bertujuan untuk melihat sejauh mana efektivitas GC dalam pembelajaran secara full online pada topik kinematika gerak parabola pada mahasiswa jurusan Sistem Komputer pada masa pandemi dan sebelum pandemi. Adapun caranya adalah mahasiswa
\end{abstract}


diberikan tiga soal tes yang berkaitan dengan gerak parabola lalu mahasiswa menjawab dan mengunggah hasil ke GC. Hasil tes menunjukkan bahawa penggunaan GC selama pandemi berjalan dengan baik. Hal tersebut dapat dilihat dari hasil pekerjaan mahasiswa dan hasil kuesioner terbuka yang diisi oleh mahasiswa. Selain itu pembelajaran dengan Google Classroom memiliki efektivitas untuk menunjang keterampilan pemecahan masalah dari mahasiswa tersebut dengan adanya dukungan media belajar daring lain yaitu video pembelajaran yang berisikan materi gerak parabola beserta contoh soal dan pembahasan.

Kata kunci: Teknologi Informasi; Google Classroom; Gerak Parabola; Keterampilan Pemecahan Masalah; Pandemi Covid 19.

\section{PENDAHULUAN}

\section{Latar Belakang Masalah}

Kinematika diajarkan pada mata kuliah Fisika. Fisika adalah mata kuliah wajib diikuti oleh semua mahasiswa S1 dari jurusan Sistem Komputer di STMIK STIKOM Indonesia. Fisika berperan sebagai ilmu dasar mempunyai andil dalam pemgembangan ilmu-ilmu lain dan melatih berpikir logis dan matematis serta berada di depan dalam perkembangan teknologi yang dibutuhkan oleh Sistem Komputer (Maharani dan Kartini, 2019). Permasalahannya adalah topik kinematika gerak parabola merupakan salah satu topik yang dianggap sulit atau sukar oleh mahasiswa sehingga dibutuhkan media bantu salah satunya adalah Google Classroom untuk mendukung proses pembelajaran di kelas. Melalui Google Classroom mahasiswa dapat mengkonstruksi kemampuanya kapan saja dan dimana saja. Dari hasil penelitian sebelumya menujukkan penggunaan Google Classroom efektif dalam mendukumg proses pembelajaran di kelas (Maharani dan Kartini, 2019).

Sejak Covid 19 melanda negara Indonesia dan banyak negara di dunia., proses pembelajaran tatap muka tidak lagi dilakukan. Pembelajaran yang dilakukan adalah sistem pembelajaran jarak jauh (online) dari jenjang TK sampai SMA bahkan Perguruan Tinggi. Hal ini menyebabkan penggunaan aplikasi GC semakin meningkat. Salah satunya adalah pembelajaran online untuk mata kuliah fisika pada jurusan Sistem Komputer topik kinematika gerak parabola.

\section{Rumusan Masalah}

Rumusan masalah dalam penelitian ini yaitu: Adakah perbedaan keterampilan pemecahan masalah mahasiswa topik kinematika pada pokok bahasan gerak parabola di Program Studi Sistem Komputer sebelum dan saat pandemi Covid 19?

\section{Kajian Teoritik}

Krulik dan Rudnik (dalam Slavin, 2000) mendefinisikan pemecahan masalah sebagai suatu usaha individu menggunakan pengetahuan, keterampilan dan pemahamannya untuk menemukan solusi dari suatu masalah. Menurut Polya (dalam Slavin, 2000) langkah-langkah penyelesaian masalah adalah memahami (understanding), merencanakan penyelesaian (planning), menyelesaikan masalah (solving) dan melakukan pengecekan kembali (checking). Sedangkan menurut Cooney (dalam Indrawati, 2014) pemecahan masalah adalah proses menerima masalah dan berusaha menyelesaikan masalah tersebut.

Menurut Slavin (2000), keefektifan pembelajaran dapat diukur menggunakan empat indikator sebagai berikut: (1) Kualitas pembelajaran yaitu seberapa besar kadar informasi yang disajikan sehingga siswa dengan mudah dapat mempelajarinya atau tingkat kesalahannya semakin kecil. Semakin kecil tingkat kesalahan yang dilakukan berarti semakin efektif pembelajaran, (2) Kesesuaian tingkat pembelajaran yaitu sejauh mana guru memastikan tingkat kesiapan siswa dalam menerima materi baru, (3) Insentif yaitu seberapa besar usaha guru memotivasi siswa untuk menyelesaikan atau mengerjakan tugas-tugas dan mempelajari materi yang diberikan. Semakin besar motivasi yang diberikan maka semakin besar pula keaktifan siswa dengan demikian pembelajaran akan efektif, (4) Waktu yaitu waktu yang dibutuhkan siswa untuk menyelesaikan kegiatan pembelajaran. Pembelajaran akan efektif apabila siswa dapat menyelesaikan pelajaran sesuai dengan waktu yang ditentukan.

Pada saat ini pembelajaran yang terpusat pada guru tidak lagi cocok pada generasi sekarang 
sehingga perlu berubah ke pendekatan yang lebih berpusat pada siswa yang amat beragam kemampuannya (Viridi. 2017). Dewasa ini aplikasi Google Classroom memang telah digunakan dalam metoda pembelajaran di dunia barat sebagai penunjang dalam kegiatan pembelajaran dan bentuk support terhadap kemajuan teknologi saat ini. Pengaplikasian Google Classroom sangat mudah digunakan dalam kegiatan pembelajaran bahkan di bulan Maret 2017 Google Classroom dapat diakses oleh semua orang melalui google pribadi. Aplikasi Google Classroom ini dapat diunduh secara gratis di perangkat berbasis android maupun iOS. Seperti yang telah diketahui bahwa kedua basis smartphone tersebut telah menjadi kebutuhan pokok di generasi 2019 ini. Beberapa fitur yang dapat dimanfaatkan guru pada Google Classroom adalah assignments, grading, communication, time-cost, archive course, mobile application dan privacy.

Penggunaan Google Classroom ini sesungguhnya mempermudah guru dalam mengelola pembelajaran dan menyampaikan informasi secara tepat dan akurat terhadap siswa (Hardiyana, 2015).

Melalui pembelajaran secara daring diharapkan dapat mengembangkan kemampuannya ke arah yang yang lebih baik. Salah satu kemampuan yang diharapkan dapat berkembang secara baik adalah kemampuan pemecahan masalah (Unaifah, 2014). Kemampuan pemecahan masalah matematis adalah suatu keterampilan pada diri peserta didik agar mampu menggunakan kegiatan matematik untuk memecahkan masalah dalam matematik, masalah dalam ilmu lain dan dalam masalah kehidupan sehari-hari (Fadillah, 2009).

\section{Tujuan Penelitian}

Adapun tujuan penelitian ini adalah membandingkan keterampilan pemecahan masalah mahasiswa jurusan sistem komputer dalam topik kinematika bahasan gerak parabola sebelum pandemi dan saat pandemi Covid-19 serta menguji efektivitas Google Classroom dalam proses pembelajaran untuk materi gerak parabola.

\section{METODE PENELITIAN}

Rancangan Penelitian
Penelitian ini dilakukan di jurusan Sistem Komputer STMIK STIKOM Indonesia menggunakan metoda penelitian Kuasi Eksperimen dengan menggunakan seluruh subjek dalam kelompok belajar (intact group) untuk diberikan perlakuan (treatment) bukan menggunakan subjek secara acak (Mustaniroh, 2015). Penelitian Eksperimen adalah metoda penelitian yang dilakukan untuk mengetahui pengaruh pemberian suatu instrumen atas perlakuan terhadap subjek penelitian (Meika dkk, 2017).

\section{Teknik Pengumpulan Data}

Data dalam penelitian ini berupa hasil tes mahasiswa dengan materi gerak parabola yang diunduh dari GC serta hasil dari kuesioner terbuka yang diberikan kepada mahasiswa melalui daring.

\section{Metode Analisis Data}

Secara umum data dianalisis secara deskriptif kualitatif yang didukung data kuantitatif untuk memperoleh gambaran tentang pengembangan keterampilan pemecahan masalah mahasiswa pada materi gerak parabola dengan langkahlangkah yang telah diuraikan (Slavin, 2000) serta melihat sejauh mana efektivitas Google Classroom tersebut dalam proses pembelajaran materi gerak parabola. Analisa data lapangan dilakukan untuk pengujian produk, menganalisis hasil pengujian serta membandingkan hasil pengujian dengan keadaan di lapangan.

\section{HASIL DAN PEMBAHASAN}

Pembelajaran fisika selama pandemic Covid-19 dilakukan secara full online. Selain menggunakan GC sebagai media pembelajaran fisika, peneliti juga menggunakan media bantu lain berupa video materi dan pembahasan gerak parabola yang diunggah bersamaan bahan ajar dalam bentuk PDF dan PPT. Berdasarkan hasil penelitian, maka secara umum mahasiswa mengerjakan tes 1, 2 dan 3 dengan menggunakan langkah-langkah pemecahan masalah, di mana mahasiswa melakukan proses untuk memahami masalah (understanding), merencanakan penyelesaian (planning), menyelesaikan masalah (solving), melakukan pengecekan kembali (checking) (Gunawan dkk, 2018)

Langkah yang ditempuh mahasiswa dalam mengerjakan tes dimulai dari apa yang diketahui, apa yang ditanyakan, kemudian strategi yang 
diperlukan untuk memperoleh pemecahan masalah dari soal tes tersebut, kemudian siswa menyelesaikan masalah tersebut dan kemudian melihat kembali atau melakukan pengecekan. Sebelum pandemi Covid-19 hal tersebut dijelaskan saat pembelajaran tatap muka. Selama pandemi. Langkah-langkah tersebut dijelaskan melalui video pembelajaran juga dalam bentuk latihan soal-soal dan pembahasanyang diunggah ke GC. Berikut adalah soal tes 1, 2 dan tes yang diberikan ke mahasiswa materi gerak parabola. Setelah soal diunggah ke Google Classroom maka mahasiswa mengerjakan soal-soal tes tersebut dan berikut contoh hasil pekerjaan dari 1 sampel mahasiswa dalam tes 1,2 dan tes 3 .

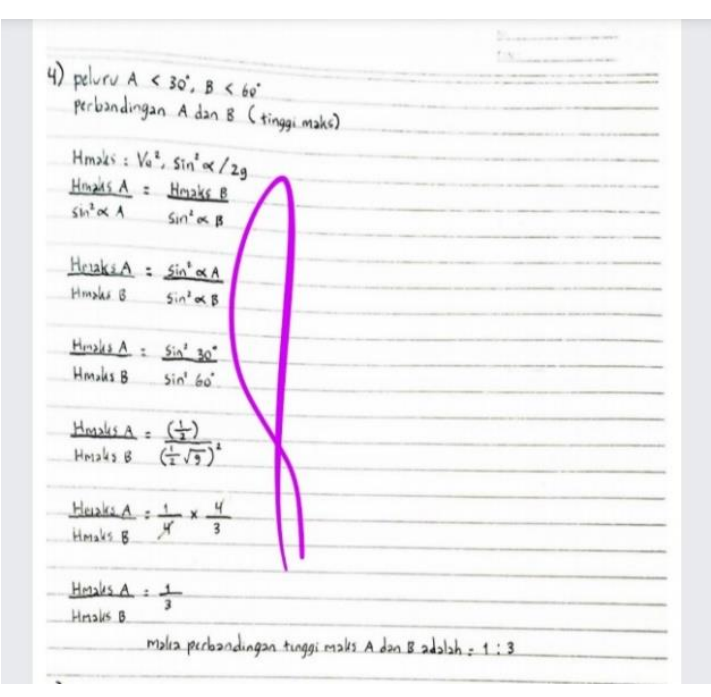

Gambar 1. Hasil Evaluasi ke 1

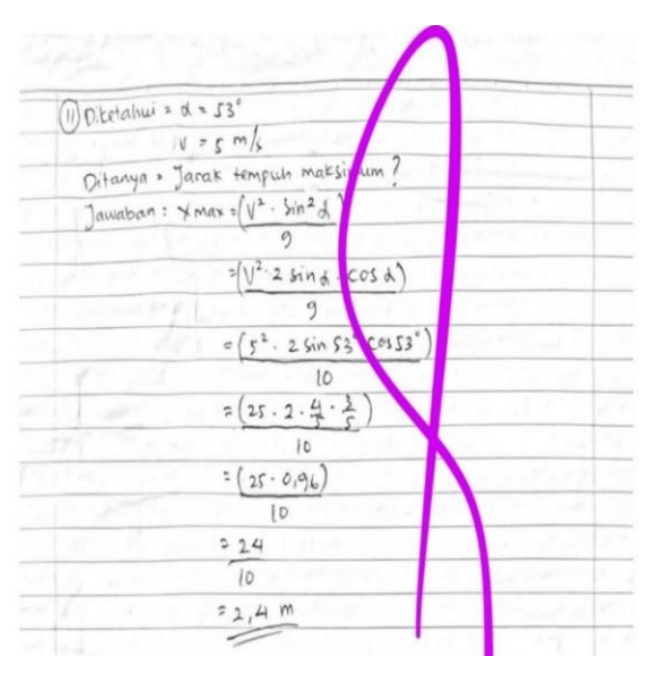

Gambar 2. Hasil Evaluasi ke 2

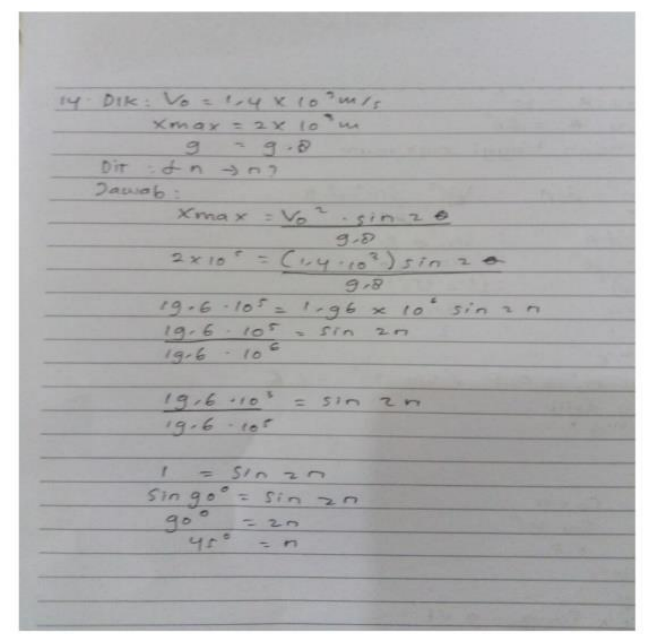

Gambar 3. Hasil Evaluasi no.3

Gambar 1 Merupakan hasil evaluasi no.1 kasus menentukan perbandingan tinggi maksimum dari dua buah sudut yang lemparan bola yang diketahui. Dari hasil tersebut dapat dilihat bahwa mahasiswa memulai langkah untuk menyelesaikan masalah dengan mengetahui terlebih dahulu apa yang dikemukakan di dalam soal, kemudian mahasiswa memahami apa yang ditanyakan dalam soal tersebut, kemudian mahasiswa mencari suatu cara/strategi yang dapat digunakan untuk memperoleh jawaban dari pertanyaan di dalam soal tersebut. Setelah itu, mahasiswa mencoba untuk menyelesaikan persoalan tersebut berdasarkan hal-hal yang telah diketahui, kemudian mahasiswa melakukan verifikasi atau pengecekan kembali hasil dari jawaban yang telah diperolehnya tersebut. Hal tersebut menunjukkan bahwa mahasiswa mengerjakan soal tes sesuai dengan langkahlangkah pemecahan masalah. Gambar 2 menunjukkan hasil evaluasi no. 2 kasus gerak parabola dalam menentukan jarak maksimum lemparan bola. Dari hasil terlihat bahwa langkahlangkah penyelesaian kasus dimulai dari menuliskan besaran-besaran apa saja yang diketahui selanjutnya merumuskan apa yang ditanyakan lalu menuliskan rumus yang sesuai dengan apa yang ditanyakan serta melakukan perhitungan. Untuk gambar 3 merupakan hasil evaluasi no.3 untuk penyelesaian soal 
menentukan besar sudut yang dibentuk saat peluru ditembakkan pada waktu tertentu.

Melalui Google Classroom, maka mahasiswa dapat belajar sendiri dari materi yang diunggah oleh pengajar dalam kelas Google Classroom yang telah dibuat. Dari materi tersebut, mahasiswa dapat menerapkan pengetahuannya tersebut untuk menyelesaikan persoalan fisika dalam tes yang diberikan sehingga mahasiswa telah mampu berpikir suatu cara yang tepat untuk digunakan dalam pemecahan masalah fisika melalui soal yang diberikan.

Keefektifan pembelajaran dengan menggunakan Google Classroom dapat dilihat berdasarkan tingkat kesalahan yang dibuat oleh mahasiswa saat menyelesaikan permasalahan yang diberikan, hal lain yang dapat menjadi acuan keefektifan pembelajaran adalah pada saat pengajar memotivasi mahasiswa untuk mempelajari materi. Selama pandemi kuliah daring untuk mata kuliah fisika membutuhkan alat bantu ajar lain berupa video-video pembelajaran yang dibuat sendiri oleh pengajar yang berisikan materi dan contoh-contoh soal beserta pembahasan. Tindakan tersebut dilakukan untuk menggantikan perkuliahan tatap muka di kelas dan dirasakan mahasiswa sangat membantu selama kuliah masa pandemi seperti ini. Berikut adalah hasil kuesioner terbuka yang diunggah mahasiswa ke Google Classroom.

Gambar 4, 5 dan 6 menunjukkan tiga contoh hasil kuesioner terbuka yang diunggah oleh mahasiswa tentang penggunaan GC selama proses pembalajaran full online selama pandemi terutama materi gerak parabola.

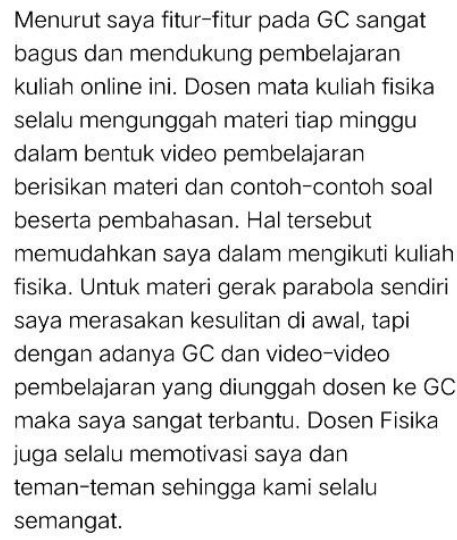

Gambar 4. Hasil kuesioner terbuka mahasiswa.

\begin{abstract}
Saya merasakan penggunaan Google Classroom efektif selama kuliah online khususnya materi gerak parabola. Dengan fitur-fitur yang dimiliki GC maka memudahkan saya dalam mendapatkan materi dan mengumpulkan tugas tepat waktu karena ada menu waktu tenggatnya. Materi gerak parabola saya rasa sulit tapi dengan media GC dan video-video pembelajaran yang diunggah dosen juga saat membantu saya dan teman-teman lainnya dalam mengerjakan soal-soal. Saya dengan mudah mengkases materi pada GC.
\end{abstract}

Gambar 5. Hasil kuesioner terbuka mahasiswa
Gambar 6. Hasil kuesioner terbuka mahasiswa.

Tabel 1. Hasil Evaluasi Mahasiswa

Tabel 1. Hasil Evaluasi Mahasiswa
\begin{tabular}{|l|c|}
\hline \multicolumn{1}{|c|}{ Nama } & Nilai \\
\hline Abdul Haris Mujibaturahman & 60 \\
\hline Anak Agung G.A. Yustikawangsa & 80 \\
\hline Antonio Frans Kotambunan & 75 \\
\hline Antonius Sumaryo Nardi & 75 \\
\hline Aprianus Yecin Hasdan & 70 \\
\hline Deni Darmawan & 80 \\
\hline Dewa Gede Dwi Ari Mahardika & 80 \\
\hline Dimas Yusuf Kristianto & 60 \\
\hline Dwi Putra Khariesman Syah & 70 \\
\hline Emanuel Stefanus Say Gere & 75 \\
\hline Emanuel Sugianto & 85 \\
\hline Erista Suryati & 90 \\
\hline Evabius Yeko Saputra & 70 \\
\hline Fandrius Jun & 70 \\
\hline
\end{tabular}

Google Classroom menurut saya mampu membantu proses kelancaran kuliah online selama pandemi. Untuk materi gerak parabola saya merasakan kesulitan pada video-video materi yang diunggah dosen memahami materi. Semua tersusun secara rapi berdasarkan pertemuan materi dan tugas-tugas tiap minggu. 


\begin{tabular}{|c|c|c|c|}
\hline I Gede Daniel Duta Narenda & 90 & Rezky Gana Surya Maulana & 79 \\
\hline I Gede Mahendra Dutha Wacihka & 80 & Rian Susandi & 90 \\
\hline I Gede Udit Apriana & 80 & Risky Andi Zainzurrahman & 75 \\
\hline I Gede Wayan Briyandita Agasena & 100 & Rizki Tri Hidayanto & 100 \\
\hline I Gusti Agung Surya Pranata & 100 & Yahya Alexander Djo Njoera & 100 \\
\hline I Gusti Bagus Surya Indrawan & 90 & Yohanes Anthony Bungama Kromen & 100 \\
\hline
\end{tabular}

Dari tabel 1 terlihat hasil yang diperoleh mahasiswa nilai minimum diperoleh 60 dan nilai maksimum 100 dengan rata-rata 84,266. Dari hasil evaluasi maka nilai mahasiswa dirujuk ke tabel 2 yaitu skor baku kampus STMIK STIKOM Indonesia.

Tabel 2. Skor Evaluasi

\begin{tabular}{|l|c|}
\hline I Made Angga Surya Andika & 80 \\
\hline I Made Arya Waras Arimbawa & 80 \\
\hline I Made Krisna Adyaksa & 70 \\
\hline I Made Mahesa Satya Darma & 87 \\
\hline I Made Merta Septiawan & 84 \\
\hline I Putu Aryx Indra Astiana & 100 \\
\hline I Putu Gede Suardana Putra & 80 \\
\hline
\end{tabular}$\quad$\begin{tabular}{|l|c|c|l|}
\hline Nilai Angka & Grade & Keterangan \\
\hline $80-100$ & $\mathrm{~A}$ & Baik Sekali \\
\hline $65-<80$ & $\mathrm{~B}$ & Baik \\
\hline $55-<65$ & $\mathrm{C}$ & Cukup \\
\hline $40-<55$ & $\mathrm{D}$ & Kurang \\
\hline $0-<40$ & $\mathrm{E}$ & Kurang Sekali \\
\hline
\end{tabular}

\section{KESIMPULAN}

Penggunaan Google Classroom untuk \begin{tabular}{|l|l|}
\hline I Wayan Pawana Aris Putra & 100 \\
\hline I Wayan Rangga Adiyasa & 100 \\
\hline
\end{tabular} mata kuliah fisika materi gerak parabola efektif selama perkuliahan online. Mahasiswa-mahaiswa secara umum dapat menjawab tes dengan baik dengan rata-rata 84,266. Hal ini didukung dengan adanya media pembelajaran lain yang digunakan seperti video - video yang berisi materi dan contoh-contoh soal pembahasan yang diunggah ke GC. Video-video tersebut sebagai pengganti kuliah tatap muka selama pandemi. Sebelum pandemi perkuliahan menggunakan GC juga efektif dengan dukungan perkuliahan tatap muka di kelas untuk materi gerak parabola (Maharani dan Kartini, 2019). Sehingga selama perkuliahan dengan GC sebagai media pembelajaran dengan fitur-fiturnya, didukung alat bantu ajar seperti video mampu memberikan kemudahan mahasiswa dalam perkuliahan online. 


\section{DAFTAR PUSTAKA}

Fadillah, S (2009). Kemampuan Pemecahan Masalah Matematis dalam Pembelajaran Matematika. Seminar Nasional Penelitian, Pendidikan dan Penerapan MIPA. Yogyakarta: Fakultas MIPA, Universitas Negeri Yogyakarta., 553-558.

Gunawan, F.I., Stefani, G.S. (2018). Pengembangan Kelas Virtual dengan Google Classroom dalam Keterampilan Pemecahan Masalah (Problem Solving) Topik Vektor pada Siswa SMK Untuk Mendukung Pembelajaran. Seminar Nasional Pendidikan Matematika Etnomatnesia. 340-348.

Hardiyana, A. (2015) Implementasi Google Classroom sebagai Alternatif dalam Meningkatkan Mutu Pembelajaran di Sekolah. Karya Tulis Ilmiah, Cirebon: SMA Negeri 1 Losari.

Iftakhar, S. (2016). Google Classroom: What Works and How? Journal of Education and Social Science, 2 (3), 12-18.

Indarwati, D., Wahyudi, W., Ratu, N. (2014). Peningkatan Kemampuan Pemecahan Masalah Matematika melalui Penerapan Problem Based Learning untuk Siswa Kelas V SD. Satya Widya, 6 (1), 17-27.

Maharani, N., K.S. Kartini (2019). Penggunaan google classroom sebagai pengembangan kelas virtual dalam keterampilan pemecahan masalah topik kinematika pada mahasiswa jurusan sistem komputer sebelum pandemi covid-19 dan saat pandemi covid-19. PENDIPA: Jurnal Pendidikan Sains, 3(3), 167-173.
Meika, I., Sujana, A. (2017). Kemampuan Berpikir Kreatif dan Pemecahan Masalah Matematis Siswa SMA. Jurnal Penelitian dan Pembelajaran Matematika, 8 (2), 8-13.

Mustaniroh, S.A. (2015). Penerapan Google Classroom sebagai Media Pembelajaran pada Pelajaran Kimia di SMK Negeri 2 Temanggung. Artikel Ilmiah, Salatiga: Fakultas Teknologi Informasi. Universitas Kristen Satya Wacana.

Slavin, R. (2000). Educational Psychology: Theory and Practice. New Jersey: Pearson Education.

Unaifah, F., Suprapto, N. (2014). Profil Kemampuan Pemecahan Masalah dan Hasil Belajar Siswa pada Materi Elastisitas ditinjau dari Gaya Belajar (Learning Style). Jurnal Inovasi Pendidikan Fisika, 3(2), 27-32.

Viridi, S., Halid, J., Kristianti, T. (2017). Penelitian Guru untuk Mempersiapkan Generasi $\mathrm{Z}$ di Indonesia. SEAMEO QITEP in Science. Bandung: P4TK IPA. 1-2. 